\title{
Multiple and stepwise regression of reproduction efficiency on linear type traits in Sahiwal cows
}

\author{
Shakeel Nouman ${ }^{1 \star}$ and Yasir Abrar ${ }^{2}$ \\ ${ }^{1}$ Livestock Production Research Institute, Bahadurnagar, Okara, Pakistan. \\ ${ }^{2}$ Livestock Experiment Station, Bahadurnagar, Okara, Pakistan.
}

\begin{abstract}
Accepted 18 October, 2012
Data on some production performance traits of 1000 milch Sahiwal cows from 3451 cows maintained at the Livestock Experiment Station, Bahadurnagar, Okara, Pakistan during the period from 2000 to 2009 were selected to study the relationship between 12 linear type traits and reproductive performance of the Sahiwal cows. The reproductive efficiency (RE) was measured in terms of calving interval from the first five lactations. The type scores were standardized for stage of lactation, age at first calving and scoring. The mean scores of linear type traits (rump width, stature, chest and body, suspensory ligament) varied from $72.6 \pm 0.78$ to $81.1 \pm 0.83$ points. The estimates of heritability $\left(h^{2}\right)$ for most of these type traits were medium $0.31 \pm 0.22$ to high $0.82 \pm 0.31$ and indicated the existence of large additive genetic variability for these traits in this breed. The phenotypic correlations of linear type traits with RE ranged between -0.1.6 \pm 0.08 and $0.10 \pm 0.09$. All the 12 linear type traits accounted for $92.96 \%$ of the variability in RE of Sahiwal cows. Step-wise regression analysis revealed that $75 \%$ of the variation accounted by all linear type traits in RE could be predicted by a sub-set of four type traits (TT) which included stature, chest and body, pelvic angle and udder depth. It was concluded that in the case of absence of records, the reproductive performance of Sahiwal cows can be predicted at an early age using some linear type traits.
\end{abstract}

Key words: Reproductive efficiency, type traits, heritability.

\section{INTRODUCTION}

Body conformation recording is not a common measurement for dairy animals in Pakistan. This is also true for Sahiwal Cattle breed. The major recorded populations of Sahiwal Cattle in Pakistan were presented at livestock experiment stations in the public sector mainly in Punjab Province. These experiment stations have been given the mandate of Sahiwal breed conservation and propagation through selective breeding. There were several challenges in linear type classification. Linear scores for different traits were dependent on several environmental and physiological factors. There is an increasing interest at the farmer level to broaden the breeding objectives and to include more traits of economic importance, especially the conformation traits (Khan,

\footnotetext{
*Corresponding author. E-mail: sn_gcu@live.com.
}

2007). Additive variance components estimated with different methods for linear type traits TT have been reported for Jerseys. Misztal et al. 1992 and Dahiya $(2005,2005 a)$ recently reported inheritance pattern for 13 linear TT for Sahiwal and Hariana cattle using paternal half-sib correlations. Several studies are available on genetic parameter estimates on conformation traits for different dairy cattle breeds in various countries. Wiggans et al. (2004) reported animal model estimates of heritability's of genetic and phenotypic correlations for 15 linear TT of Ayrshire, Brown Swiss and Guernsey and 14 traits for Jersey. Such estimates for udder traits were reported by Rupp and Boichard (1999) for French Holsteins. Earlier, Gengler et al. (1997) reported genetic parameters for linear TT for US Jersey cows while Musarrat et al. (2008) reported genetic and phenotypic correlations among TT of Guernsey cows using a sire model. Heritability estimates of linear TT for Holstein cows 
with sire model have also been reported.

Recently more emphasis on individual linear TT has been advocated in contrast to genetic selection for final type score. Functional type should received proper attention to capitalize on the high production breed into the modern dairy cow. Dairy cattle breeders in the developed countries have studied the genetic importance of linear TT but critical appraisal of the same are sporadic and limited in Pakistan breeds. Hence, the present investigation was undertaken to identify useful linear TT for prediction of RE in Sahiwal cows.

\section{MATERIALS AND METHODS}

Phenotypic data and animal measurements were collected and taken from 1000 in milk cows selected from 3451 animals. A measuring tape $(\mathrm{cm})$ was used for all measurements. Data were analyzed through statistical software SPSS 17 version and GenStat $12^{\text {th }}$ edition to see the scores for 12 individual TT according to linearized type scoring system (Trimberger et al., 1987). In this system individual linear TT were scored on 50 point scale (50-99 points) in which biological extremes of the traits were considered, that is, minimum to maximum degree rather than desirability was considered. Each cow was scored thrice just before milking. Within 21 days, three measuring of all type traits on one animals measured and average of this taken as a result to reduce the error percentage. For all the traits with an interval of 1 week and the average score for each trait was taken to minimize any bias of a particular day. Data on age at first calving, age at scoring and stage of lactation were also collected to standardize the type scores for these factors. RE of the cows was measured in terms of length of calving interval from the first five calving of each animal. The data were analyzed using a linear mathematical model containing stage of lactation as a fixed effect, age at first calving as random effects and age at scoring as covariates.

Heritability and correlations were estimated by the paternal half-sib correlation method after adjusting the data for significant effects by least-squares approach by GenStat $12^{\text {th }}$ edition software. Multiple and stepwise regression techniques Fooster et al., (1989) were utilized to study the effect of linear TT on RE and to find out important linear TT for the prediction of RE through SPSS 17 version software.

\section{RESULTS AND DISCUSSION}

The linear type scores were standardized for stage of lactation, age at first calving and age at scoring. Effect of stage of lactation was significant $(P<0.05)$ for stature, rump width, rear udder height, teat placement and udder depth. Age at first calving affected significantly only stature, fore udder attachment, rear udder width, whereas all the traits except foot shape and pelvic angle were affected by age at scoring. Meyer et al., 1987, Filiz Akdağ, 2011 and Toghiani (2011) also reported significant effect of these factors of some linear TT. The average score of all linear TT was computed after removing the significant effect of these factors and given in Table 1. The scores for form traits were in medium class (70 to 80 points) except pelvic angle indicating that an average Sahiwal cow was an intermediate in height and body capacity, having well formed feet, slight set in hock for rear legs and moderate slope from hooks to pins. The scores for udder TT ranged from 72.67 to 78.95 points and revealed that the attachment of fore udder in Sahiwal cows was neither extremely tight nor broken, udder was of intermediate width, teats were centrally placed and nearly aligned and tilting inward and udder floor was at the hock.

The $\mathrm{h}^{2}$ estimates of various type TT given in Table 1 revealed that pelvic angle had the lowest $h^{2}(0.07 \pm 0.26)$ followed by foot shape $(0.13 \pm 0.30)$ in all linear TT. The $h^{2}$ estimates for stature, dairy character, rear legs, fore udder attachment and udder depth were moderate, whereas the estimates for all other form and udder traits were medium to high. The $h^{2}$ estimates in the present study were higher than those reported for various exotic breeds of cattle (Meyer et al., 1987; Musarrat et al. (2008); Gengler et al., 1997; Rupp and Boichard, 1999). High estimates of $h^{2}$ were also reported by Musarrat et al. (2008) in Sahiwal cattle. The high $\mathrm{h}^{2}$ estimates for some linear TT in Sahiwal breed are clearly indicative of the existence of large additive genetic variability which in turn suggests that these traits have hardly been subjected to selection. Therefore, appropriate attention needs to be directed for the utilization and genetic improvement.

The phenotypic correlations of linear TT with RE (Table 1) revealed that stature and chest and body had moderate and negative relationship with RE suggesting that tall and strong cows lend to have shorter inter calving period as also reported by Burnside et al. (1984) and Dadati et al. (1986) in exotic cattle. Total number of recorded in milk animals was 1000 selected from 3541 animals. Each herd was comprised of approximately 1100 animals and the duration was 2000 to 2009.

In this study, the highest positive correlation $0.10 \pm 0.09$ was observed in dairy character. The average score of dairy character was $79.62 \pm 0.81$ and heritability was $0.31 \pm 0.22$. The foot shape angle average score was $76.55 \pm 0.92$ heritability was $0.13 \pm 0.05$ and the correlation value was $0.03 \pm 0.01$. The values of chest and body, and stature were $74.24 \pm 0.84$ and $73.26 \pm 0.82$ and the correlation was $-0.27 \pm 0.08$ to $0.31 \pm 0.08$, respectively. All the aforementioned results are similar with the findings of Canadian Holstein Association (1995)

Most of the coefficient among chest and body had negative signs. Udder depth corresponds to the distance between the bottom part of the udder and the hocks (Canadian Holstein Association, 1995). However, research by Van Vleck and Norman (1972) showed a negative genetic correlation between udder depth and lifetime production (Canadian Holstein Association, 1995).

Udder depth and teat placement rear view had negative correlations with all body traits; most of the correlation had low medium range. Correlation of foot shape (angle), fore udder attachment, pelvic angle, rear legs, rear udder width, rump width and suspensory ligament had low range. A phenotypic correlation of -0.16 was estimated between pelvic angle and $R E$ which was similar to the findings of Van Vleck and Norman (1972) and Honnette et 
Table 1. Average score, $h^{2}$ estimates and phenotype correlations of linear TT with RE in Sahiwal cows.

\begin{tabular}{lccc}
\hline Trait & Average score & $\mathbf{h}^{2} \pm \mathbf{S E}$ & $\mathbf{r}_{\mathrm{p}} \pm \mathbf{S E}$ \\
\hline Chest and body & $74.24 \pm 0.84^{\mathrm{b}}$ & $0.48 \pm 0.12^{\mathrm{c}}$ & $-0.27 \pm 0.08^{\mathrm{e}}$ \\
Dairy character & $79.62 \pm 0.81^{\mathrm{a}}$ & $0.31 \pm 0.22^{\mathrm{d}}$ & $0.10 \pm 0.09^{\mathrm{a}}$ \\
Foot shape (angle) & $76.55 \pm 0.92^{\mathrm{b}}$ & $0.13 \pm 0.05^{\mathrm{e}}$ & $0.03 \pm 0.01^{\mathrm{b}}$ \\
Fore udder attachment & $75.32 \pm 0.97^{\mathrm{b}}$ & $0.33 \pm 0.11^{\mathrm{d}}$ & $-0.08 \pm 0.0 \mathrm{~d}^{\mathrm{d}}$ \\
Pelvic angle & $81.16 \pm 0.81^{\mathrm{a}}$ & $0.07 \pm 0.01^{\mathrm{e}}$ & $-0.16 \pm 0.08^{\mathrm{d}}$ \\
Rear legs (side view) & $75.24 \pm 0.97^{\mathrm{b}}$ & $0.35 \pm 0.06^{\mathrm{c}}$ & $-0.03 \pm 0.01^{\mathrm{c}}$ \\
Rear udder width & $75.35 \pm 0.70^{\mathrm{b}}$ & $0.63 \pm 0.15^{\mathrm{b}}$ & $0.02 \pm 0.01^{\mathrm{b}}$ \\
Rump width & $72.67 \pm 0.78^{\mathrm{c}}$ & $0.82 \pm 0.31^{\mathrm{a}}$ & $0.04 \pm 0.02^{\mathrm{b}}$ \\
Stature & $73.26 \pm 0.82^{\mathrm{c}}$ & $0.27 \pm 0.10^{\mathrm{d}}$ & $-0.31 \pm 0.08^{\mathrm{e}}$ \\
Suspensory ligament & $76.12 \pm 0.81^{\mathrm{b}}$ & $0.53 \pm 0.21^{\mathrm{c}}$ & $0.04 \pm 0.01^{\mathrm{b}}$ \\
Teat placement & $76.71 \pm 0.74^{\mathrm{b}}$ & $0.27 \pm 0.09^{\mathrm{d}}$ & $-0.04 \pm 0.01^{\mathrm{c}}$ \\
Udder depth & $78.95 \pm 6.62^{\mathrm{a}}$ & $0.35 \pm 0.06^{\mathrm{d}}$ & $-0.12 \pm 0.05^{\mathrm{d}}$ \\
\hline
\end{tabular}

$h^{2}$, Heritability; rp, phenotype correlations significant $(P<0.05)$ and non significant $(P>0.05)$ means of triplicate experiment; means sharing same letter in column are statistically non significant by Tuckey's T-Test at 0.05 level of significance.

Table 2. Statistical analysis for RE on linear TT in Sahiwal cows.

\begin{tabular}{clcc}
\hline \multirow{2}{*}{ No. } & Trait & \multicolumn{2}{c}{ Regression analysis } \\
\cline { 3 - 4 } & & Multiple & Stepwise \\
\hline 1 & Intercept & 3233.53 & 2669.72 \\
2 & Stature & -11.13 & -9.02 \\
3 & Chest and body & -1.75 & -1.85 \\
4 & Dairy character & 9.24 & - \\
5 & Foot shape (angle) & -1.96 & - \\
6 & Rear legs (side view) & -3.69 & - \\
7 & Pelvic angle & 2.88 & 3.21 \\
8 & Rump width & -0.38 & - \\
9 & Fore udder attachment & 0.47 & - \\
10 & Rear udder width & 2.66 & - \\
11 & Teat placement & -1.15 & - \\
12 & Suspensory ligament & -6.79 & -7.92 \\
13 & Udder depth & -7.84 & 97.22 \\
14 & R & $92.96^{*}$ & \\
\hline
\end{tabular}

${ }^{*}$ Coefficient of determination: Is the ratio of the explained variation to the total variation.

al. (1980) who reported that cows with sloping rumps were having shorter calving intervals than those with level rumps. Among udder traits, udder depth had moderate phenotypic correlation with $\mathrm{RE}$ as -0.12 indicating that cows having deep udders had shorter calving interval periods. Such type of relationships between udder traits and reproductive attributes were also reproduced by Honnette et al. (1980) and Dadati et al. (1985).

Inter and intra-correlations of type reproductive performance traits may result in difficult on liner TT reproductive performance in early life. Keeping these findings in mind, step-wise regression procedure was carried to know the best combination of few linear type traits which have some predictability for RE (Table 2).
The total contribution of all linear $\Pi T$ towards the variation in $\mathrm{RE}$ was $92.96 \%$. The highest estimate of partial regression coefficient among non-udder trait was for stature -11.13 highlighting its importance in production of RE in this breed. Among udder traits, udder depth showed the highest partial regression coefficient.

Step-wise regression analysis revealed that $75 \%$ of the contribution by all linear $T T$ towards RE could be measured by a sub-set of four TT. This group included stature, chest and body, pelvic angle and udder depth. It means that reproductive ability of Sahiwal cows can be judged at an early age with the help of these four linear TT in the absence of records for reproductive attributes. Musarrat et al. (2008) reported that broad body and good 
udder shape had the higher index values for reproductive ability in cows.

Tozser et al. (1999) also reported that after 13 steps of backward step-wise regression, only 9 out of the original 22 type traits were incorporated in the regression equation and multiple correlations co-efficient did not change substantially after thirteen step of analysis.

\section{Conclusions}

It was concluded that high magnitude of heritability for some linear type traits and their association with reproductive performance; these twelve traits can be utilized for maintaining RE in high producing Sahiwal cows. The regression analysis revealed that the reproductive performance of Sahiwal cows can be judged in early life with the help of few type traits such as stature, chest and body, pelvic angle and udder depth.

\section{REFERENCES}

Burnside EB, Mc Cliniock AE, Hammond K (1984) Type, production and longevity in dairy cattle. Anim. Breed. Abstr. 52(10):711-719.

Canadian Holstein Association (1995) The Contribution of Genetic Parameters to the Profitability of Canadian Holstein Cows. Holstein Canadiennes; Functionless at Profitables., Department of Agricultural Economics, McGill University, Montreal, National Library of Canada, Wellington Street Ottawa. p. 395

Dadati E, Kennedy BW, Burnside EB (1985) Relationships between conformation and reproduction in cows. J. Dairy Sci. 68(10):2639-45.

Dadati E, Kennedy BW and Burnside EB (1986) Relationships between conformation and calving interval in Holstein cows. J. Dairy Sci. 69(12):3112-19.

Dahiya SP (2005). Linear functional type traits for reproductive efficiency in Hariana cows. Indian J. Anim. Sci. 75:524-527.

Dahiya SP (2005a). Appraisal of linear type traits for reproductive efficiency in Sahiwal cows. Indian J. Anim. Sci. 75:945-948.
Filiz Akdağ, Serhat Arslan, Alaattin Caynak, Bulent (2011). The relationships of phenotype, genotype and some environmental factors with birth weight in Jersey calves Afr. J. Biotechnol., 10 (37): 7308-7313.

Fooster WW, Freeman AE, Berger PJ, Kuch A (1989). Association of type traits scored linearly with production and heard life of Hostelin. J. Dairy. Sci. 72: 2651-2664.

Gengler N, Wiggans GR, Wright JR, Norman HD, Wolfe CW (1997). Estimation of covariance components for Jersey type traits using a repeatability model. J. Dairy Sci. 80:1801-1806.

Honnette JE, Vinson WE, White JM, Kliewer RH (1980) Prediction of herd life and life time production from first lactation production and individual type trait in Holstein cows. J. Dairy Sci. 63(5):816-824.

Khan MS (2007). Research efforts for conservation and development of Sahiwal breed. Proceedings of National Workshop on Sahiwal Cattle "Development of Indigenous Resources-The Sahiwal Cattle Breed", April14. Dept. Animal Breeding and Genetic, University of Agriculture, Faisalabad.

Meyer K, Brotherstone S, Hill WG, Edwards MR (1987) Inheritance of linear type traits in dairy cattle and correlations with milk production. Anim. Prod. 44: $1-10$.

Misztal I, lawlor TJ, Short TH and Vanraden PM (1992). Multiple trait estimation of various component of yield and type traits using an animal model. J. Dairy. Sci. 75:554-551.

Musarrat AK, Muhammad SK, Arshad I (2008) Genetic and Phenotypic correlations among linear type traits in sahiwal cows, Pak. J. Agri. Sci., Vol. 45(2).

Rupp R, Boichard D. (1999). Genetic parameters for clinical mastitis, somatic cell score, production and udder TT and milking ease in first lactation curve. J. Dairy Sci. 82(10):2198-2204.

Toghiani S (2011). Genetic parameters and correlations among linear type traits in the first lactation of Holstein dairy cows. Afr. J. Biotech.10(9):1507-1510.

Tozser J, Balika S, Kovacs A, Bcdo S (1999). Evaluation of classification in the Limousin breed. Acta Agron. Hung. 47(4):429434.

Trimberger GW, Etgen MW, Galton DM (1987). Dairy cattle judging techniques. CAB Direct. PP. XII + 356. ISBN 0-13-196007-5.

Van Vleck LD, Norman HD (1972). Association of type trait with reasons for disposal. J. Dairy Sci. 55:1823.

Wiggans GR, Gengler N, Wright JR (2004). Type trait covariance components for five dairy breeds. J. Dairy Sci. 87:2324-2330. 